MARKETING AND BRANDING
RESEARCH $\begin{gathered}\text { INDUSTRIAL } \\ \text { MANAGEMENT } \\ \text { INSTITUTE }\end{gathered}$

\title{
Formulating the supply chain strategy of automotive industry in Iran using balanced Scorecard, System Dynamics, and Game Theory
}

\author{
Ghasem Farajpour Khanaposhtani ${ }^{{ }^{*}}$, Seyyed Shahrokh Jafari², Farhad Ariana ${ }^{2}$, Amir \\ Alaie $^{2}$, Hamed Salimi ${ }^{2}$ \\ ${ }^{1}$ Assistant professor, Department of Industrial Engineering, Parand Branch, Islamic Azad University, Parand, \\ Iran \\ ${ }^{2}$ MSc student of industrial engineering (system and productivity), Parand University, Tehran, Iran
}

\begin{tabular}{|c|c|}
\hline & ABStrACT \\
\hline $\begin{array}{l}\text { Keywords: } \\
\text { Supply Chain, System } \\
\text { Dynamics, Game } \\
\text { Theory, Shapley Value }\end{array}$ & $\begin{array}{l}\text { The current study focuses on the necessity of using strategic planning in supply chain } \\
\text { management of an organization in order to apply the opportunities and face the threats } \\
\text { through formulating the appropriate strategy by means of game theory and system dynamics. } \\
\text { It also studies the Automotive Industry in Iran from four main aspects to implement } \\
\text { different strategies. At first, the main variables of supply chain are identified, then causal } \\
\text { diagrams are created in the form of feedback relationships. In the next stage, the variables of } \\
\text { surface and rate are identified to draw the model of surface and flow; finally, simulation } \\
\text { equations for } 10 \text { years are presented. Selecting the best mixed strategy as a game with four } \\
\text { players has been considered and each player (aspect) can select three strategies. At the end, } \\
\text { through the concept of Shapley, the effectiveness of each player in providing utility is } \\
\text { measured and by means of decision tree, the best mixed strategy is selected. The results } \\
\text { indicated that manufacturers will play the greatest role in the future of Automotive Industry } \\
\text { in Iran. }\end{array}$ \\
\hline
\end{tabular}

(C)AIMI Journals

\section{Introduction}

One of the common philosophies over two recent decades which has significantly developed the industrial countries in terms of production is supply chain management (Norang \& Mehryar Irdimousa, 2012). Supply chain includes all the activities connecting suppliers, raw materials, and/or services to producers and consumers (or customers). The initial aim of any 
supply chain is to meet the customer's needs through the process making profit for the supply chain. Therefore, the aim of supply chain management is to maximize the profitability of supply chain and customer's satisfaction (Stadtler \& Kilger, 2004). Today, due to the variable condition of the market and customers' various demands as well as the fierce competition between the producers of goods and services in the market, supply chains adopt appropriate strategies to reduce the costs and qualitative attitudes and increase their efficiency, so that they can survive under different circumstances (Chopra \& Meindl, 2007). Chang and Ellinger (2014) evaluated supply chain risk mitigation strategy and considered the relationship between supply chain risk management and formulating strategy to reduce the risk of the organization. Regarding the importance of applying balanced scorecard in evaluating the performance of supply chain strategy, we can refer to its holistic nature as a comprehensive system of evaluating performance. In fact, balanced scorecard allows managers to use an official mechanism and keep a balance between financial and non-financial indices in the short-term and long-term. Moreover, it evaluates the performance of an organization through four traditional views, namely financial, the process of internal business, customer, and growth and learning (Afonso \& Rosario Cabrita, 2015). Since supply chain is implemented in dynamic and variable environment, considering the dynamics of relationships, aims, and the effective factors is of great importance. In this regard, using system dynamics approach in determining the relationship and interaction of these aims leading to the accomplishment of the final aim can be effective as a causal loop diagram (Tatikonda \& Tatikonda, 1998). Saad, Mohamed Udin, and Hasnan (2014) studied the capabilities of dynamic supply chain and stated that system dynamics are capable of simulating different supply chains. By means of this simulation, the uncertain consequences of decisions become noticeable. The main aim of this method is to facilitate the learning of systems behavior in present and future. Today, most organizations especially small industries and organizations are facing fierce competition and uncertain environment, which has become more severe due to the technology innovations and customers' variable needs. Under such circumstances, the previous approaches in supply chain lose their capabilities. System approach to supply chain is one of the solutions to face such challenges (Azar, Moghabel Baarz, \& Anvari Rostami, 2011). Tian, Govindan, and Zhu (2014) have presented a system dynamics model based on evolutionary game theory to diffuse green supply chain management among Chinese manufacturers. In fact, as a case study in Automotive Industry in Iran, it has been attempted to study some key variables of this industry and present a strategic map of chain supply based on system dynamics approach. In this research, first, the main variables of supply chain are identified and causal diagrams are created in the form of feedback relationships. Then, the variables of surface and rate are identified, the model of surface and flow are created, and the equations of simulation model for 10 years are presented. Moreover, the automotive industry was studied and four main aspects were identified to implement different strategies. Selecting the best mixed strategy as a game with four players was considered and each player (aspect) could select three strategies. At the end, through the concept of Shapley, the effectiveness of each player in providing utility was measured and by means of decision tree, the best mixed strategy was selected. 


\section{The Literature Review}

According to some experts, the concepts of system dynamics are the basis of any system thought. However, most researchers assume that system dynamics are one of the approaches to think about the consequences of people's decisions. In system dynamics, sources are related to the physicality of the system and are the focus of transformation process happening within the system. Surfaces indicate the mode of system at any point. Even if the rate value becomes zero, surfaces will exist. Surfaces can absorb the changes in flows. Rate variables, unlike surfaces, immediately will become zero if the system stops working. In fact, the flow diagram indicates the relationships between rate and surface variables in system dynamics (Sushil, 2014).

Games theory as a new branch of mathematics has adopted a new approach to decisionmaking and attracted many researchers' attention in recent years. This science studies people's decision-making when they interact with others. In other words, games theory is the science of studying conflicts and cooperation between wise players. The main aim of games theory is to express attitude and according to that, players must behave wisely. A game includes a group of players, a group of strategies and actions, and a certain outcome for each strategy. Generally, games theory is divided into two main branches including cooperative and non-cooperative games.

In cooperative games, players are allowed to cooperate and the main aim of these games is to provide a method for sharing the profit fairly. These games studied static form and the functions of players' utility can be expected or definite. An n-person cooperative game in characteristic function form is a pair of $\mathrm{G}(\mathrm{N}, \mathrm{V})$, where $\mathrm{N}$ is a limited set with n members $\mathrm{N}=$ $\{1,2, \ldots, n\}$ and $N$ is the set of players. The subset of $(S, S \subseteq N)$ is called coalition.

For an N-person cooperative game, Shapley has calculated the average revenue of each player from coalitions. In fact, the revenue value of $u_{i}^{*}$ for the player i is calculated through this concept.

If the player i joins the coalition $\mathrm{C}$, their final efficiency will be defined as:

$$
\{V(C)-V(C-(i))\}
$$

Assuming that coalitions totally and generally are formed by coalition of one to two and to $\mathrm{N}$-person and any order of joining to coalitions is probable, $u_{i}^{*}$ for the player $\mathrm{i}$ indicates their final average efficiency, as:

$$
u_{i}^{*}=\sum_{\substack{C \subset N \\ i \in C}} \frac{(k-1) !(N-k) !}{N !}\{V(C)-V(C-(i))\}
$$

$\mathrm{N}$ : total players

$\mathrm{C}: \mathrm{k}$ : the number of players in coalition

The probability of any coalition: $\frac{(k-1) !(N-k) !}{N !}$

The equation (2-2) is solved through the sum of calculations, for each possible coalition of the player $\mathrm{i}$. The Shapley value of $u_{i}^{*}$ can identify the power of player $\mathrm{i}$ in their sensitivity and effectiveness to win a coalition. This power depends on the increase in the efficiency of a coalition to join the player i to that coalition (Leng \& Parlar, 2005). 
In 1990s, the model of balanced scorecard was welcomed first as a modern method of evaluating the performance and then as a tool to help to implement the strategy by the experts of management and the managers of organizations. It is possible that an organization has achieved good economic results in past and according to those results, it has based its future planning on the results of previous years. Therefore, all the evaluations of this organization is based on the evaluations of previous years (a retrospective evaluation). However, this evaluation is not able to answer this question: where is the organization moving towards? This sort of evaluation is similar to a driver who only looks at the rear-view mirror and pays attention to the behind and ignores the cars moving towards him. Due to the high speed in the current international trade, the needs of organization to comprehensive evaluations have been highlighted. In order to prepare the managerial system of the organization, keep pace with the current speed of trade, make the information needed by the management available, and make right decisions, balanced scorecards were created. Balanced scorecard is a managerial system supporting the organization in arranging the route and achieving the key strategic aims. The creators of balanced scorecards proposed four main aspects which are shown in Figure 1 (Rezaee Ghahraman, Aghaseyyed Hosseini, \& Ahmadian, 2012).

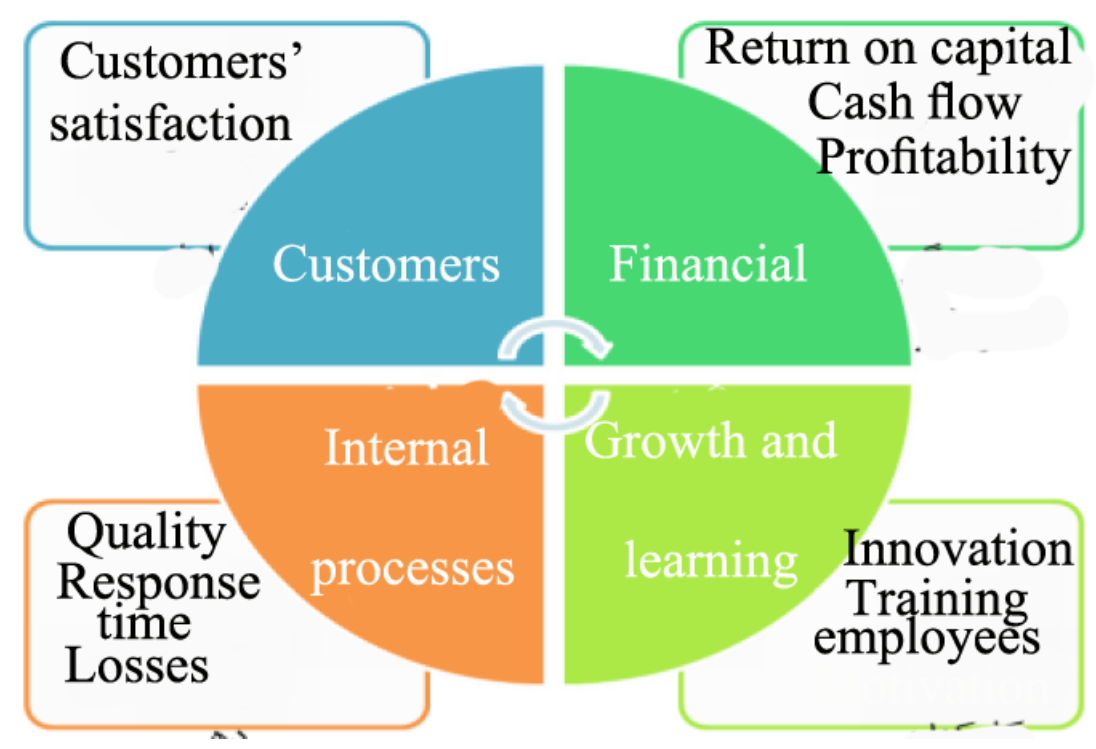

Figure 1. Four main aspects of balanced scorecard

Supply chain includes all the activities related to the flow and conversion of goods from raw materials to delivering them to the final consumer as well as information flows related to them. Supply chain management includes the integration of supply chain activities and information flows related to them through improving chain relationships in order to achieve reliable competitive advantage (Jalali Naini, Aliahmadi, \& Jafari Eskandari, 2011).

\section{Results}

The suggested framework for selecting the optimum strategy of supply chain is developed in six steps. In the first step (investigating the studied industry), a general view of the industry and its place in future according to high-level documents such as the aims and policies of developing the industry is illustrated. 
In the second step (identifying the relationships between the levels of supply chain), key elements in supply chain are identified and defined through studying the research literature and interviewing the experts of the desired field.

In the third step (identifying cause and effect relationships), based on the studies of the previous steps, cause and effect diagrams are illustrated and according to the experts' opinions, the validity of cause and effect relationships is measured.

In the next step (creating flow diagram based on cause and effect relationships in supply chain), according to the previous step and cause and effect diagrams, surface and rate variables are identified and by means of historical data, interview, questionnaire and Vensim Software, the equations of model is written.

In the fifth step (simulating and analyzing the results and suggesting the strategy to improve the performance of supply chain), the model created in the previous step is implemented and the simulation results are analyzed. Moreover, through comparing the results with high-level documents, different strategies in four aspects are suggested.

In the last step (selecting the optimum strategy), according to the simulation results in the previous step, the best mixed strategy as a four-player game is selected using the concept of Shapley value.

Formulating and selecting the optimum strategy for Automotive Industry in Iran is accomplished in six steps. In the first step, Automotive Industry in Iran is studied. Automotive Industry in Iran includes two main grand companies, namely Iran Khodro Company and Saipa Company. Studying these two companies leads us to an evaluation of Automotive Industry in Iran. The number one ranking in the Middle East, five in Asia, and eleven in the world rankings are achieved by means of competitiveness based on technology development.

In the second and third steps (identifying the relationships between the levels of supply chain and cause and effect relationships between the elements), the main elements of supply chain and cause and effect relationships between them are identified. To identify these relationships, we can use questionnaire, interview experts, study the related papers, and investigate their logical relationships. The cause and effect diagram has been divided into four main parts including demand, production, sale, and distribution. For each part, a separate cause and effect diagram was formulated and finally by combining these four cause and effect diagrams, the general cause and effect diagram was illustrated as it is depicted in Figure 2. 


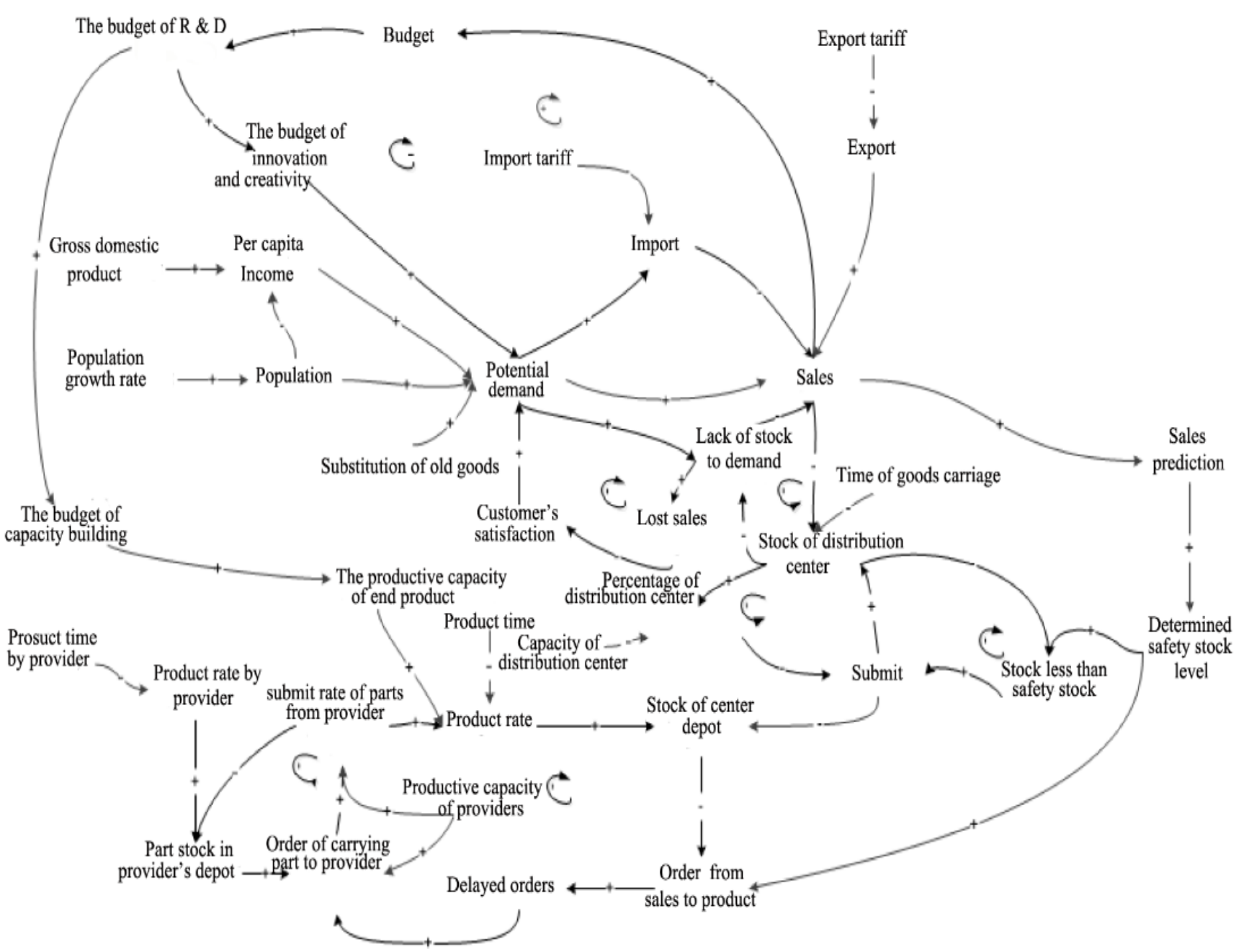

Figure 2. Cause and effect diagram of supply chain in Automotive Industry in Iran

In the fourth step (creating the flow diagram according to the cause and effect relationships in supply chain), surface and rate variables are identified and the equations of model are created in Vensim. The flow diagram is illustrated in Figure 2. In order to write the equations, historical data, time series, experts' opinions, questionnaire, and interview were used. Figure 3 presents the flow diagram of supply chain in Automotive Industry in Iran. 


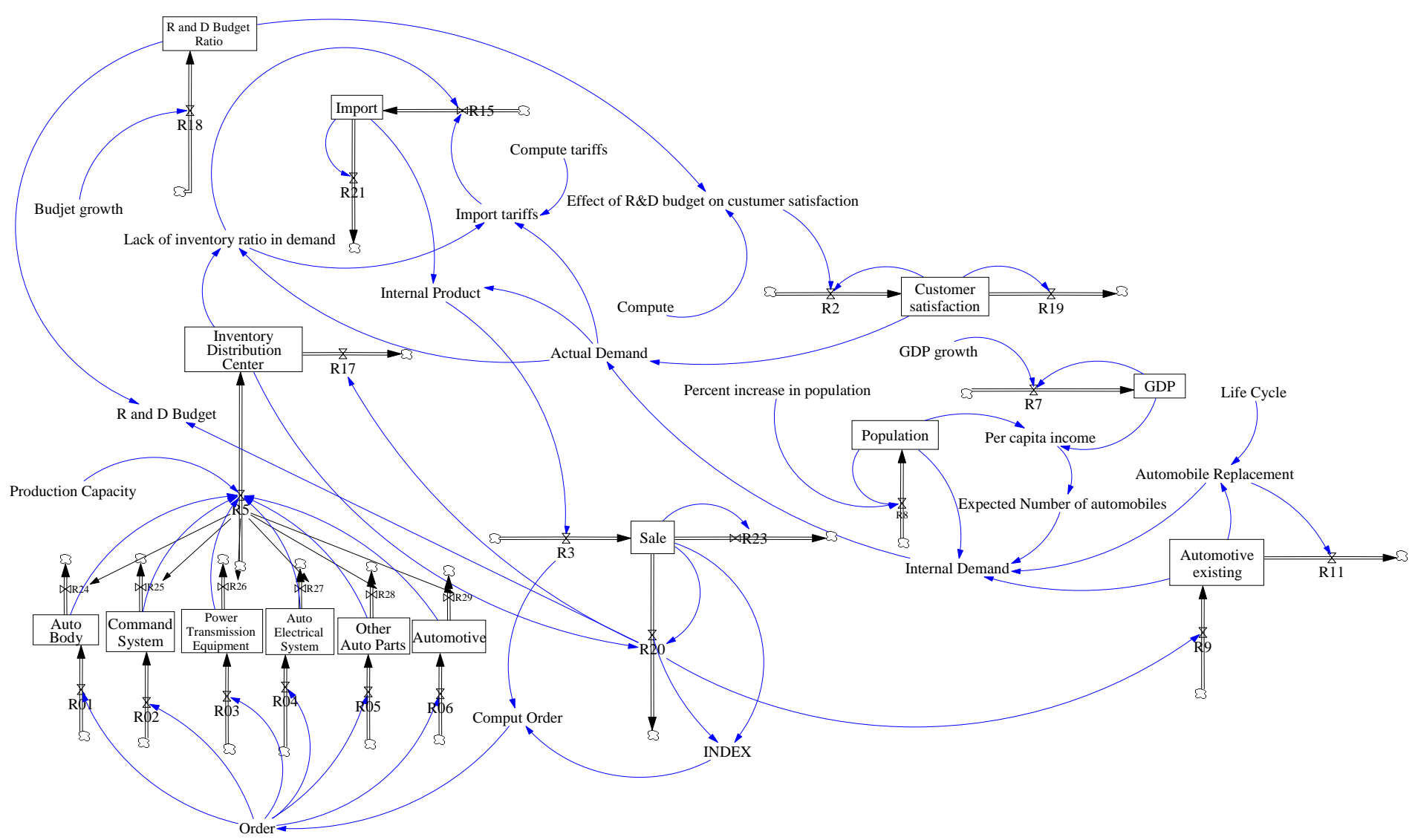

Figure 3. Flow diagram of supply chain in automotive industry in Iran

In this model, it is assumed that all predicted demands are not transformed into real demands. In other words, only a few percentage of potential demand is transformed into actual demand. In order to write the equation of the percentage transformed into real demand, customer's satisfaction was considered. Moreover, it was assumed that an automobile consists of six main sets and providers are categorized into these six main sets. These sets include auto body, electricity, engine, steering wheel, auto power transmission, and other parts.

It was also assumed that each person's per capita income affects the auto demand. Therefore, gross national income was applied in this model. In this model, to determine import tariff directly affecting import in proportion to stock lack of auto distribution center, actual demands are considered. Three main parts for sales of domestic automakers were taken into account. The first part includes a percentage of actual demand which must be provided by domestic product. The second part is a part of this domestic product which is produced with delay or cannot be produced and is lost.

In the fifth step (simulating and analyzing the results and suggesting a strategy to improve supply chain performance), the model was implemented for 10 years. The results of simulation indicate that as gross national income and population increase, per capital income changes. According to the capacity of production and the current average life of the country's automobiles, which is more than 15 years, at the beginning of simulation, the process of substitution is faster than the process of production; thus, the number of automobiles 
decreases. After the delay in producing and substituting new cars, the number of automobiles increases and in the final years of simulation, the average life of cars becomes 15 years and the process of increasing the number of automobiles begins. According to the process of substitution and changes in per capita income, demand was at first growing rapidly, but in the final years of simulation it was moderated. Customer's satisfaction changes according to the budget for research and development. At the beginning of simulation, this budget is limited, but as time passes, it grows and increases satisfaction. The results of implementing the model are illustrated in Figures 4, 5, and 6.
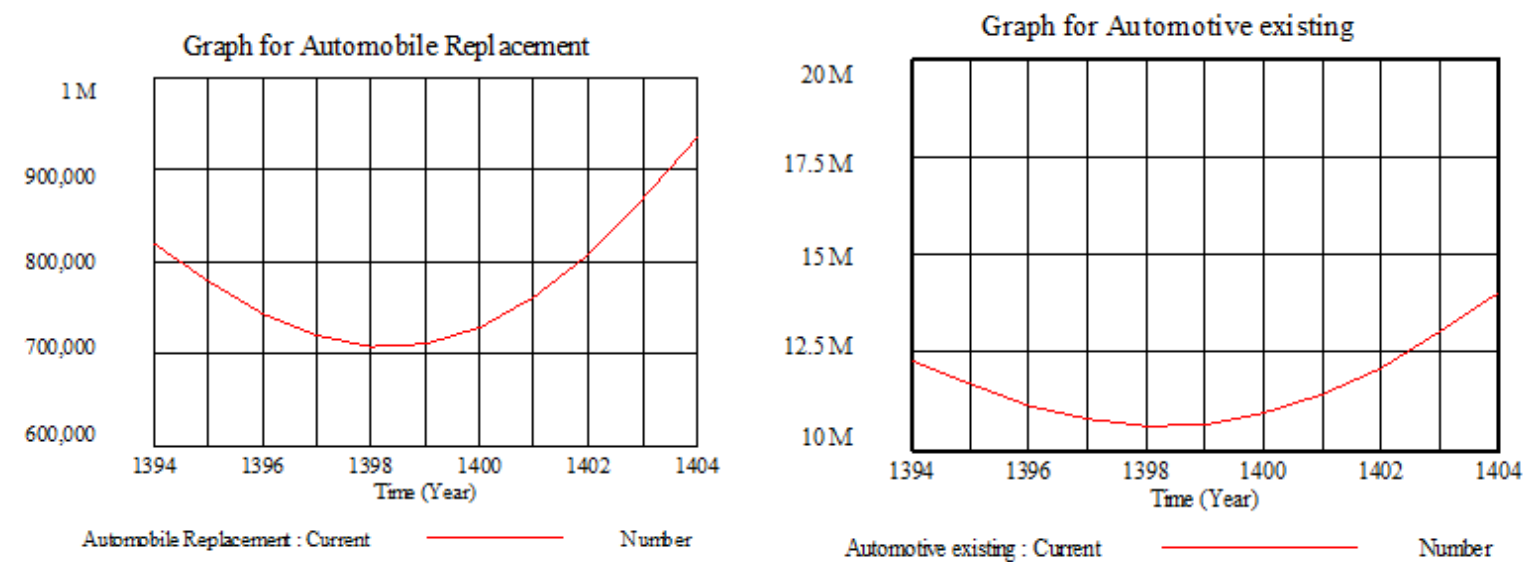

Figure 4. The result of simulation for variables of the number of available automobiles and substitute automobiles

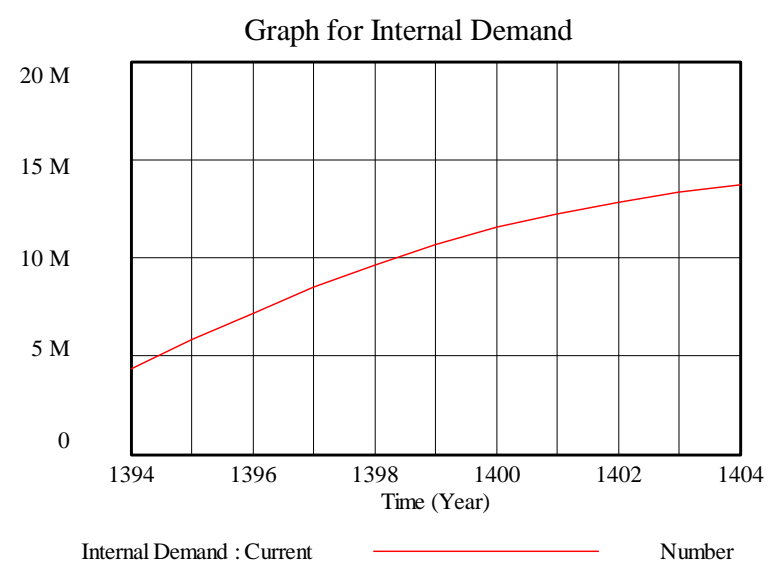

Figure 5. The result of simulation for variable of domestic demand for automobile 


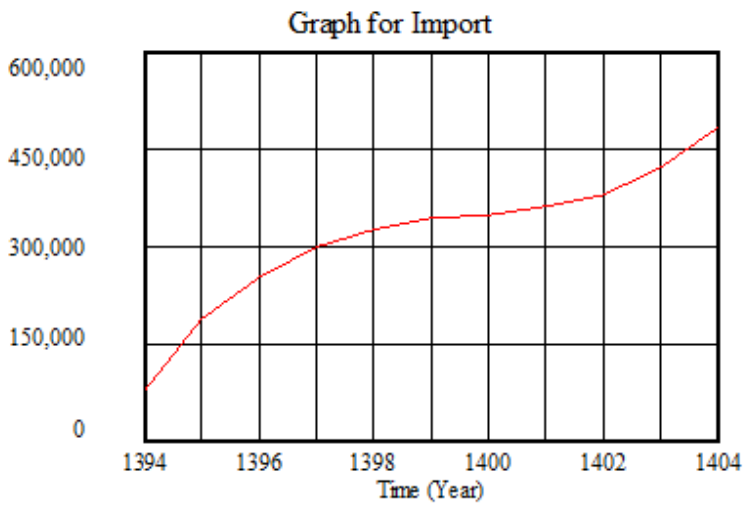

Import : Current

Number

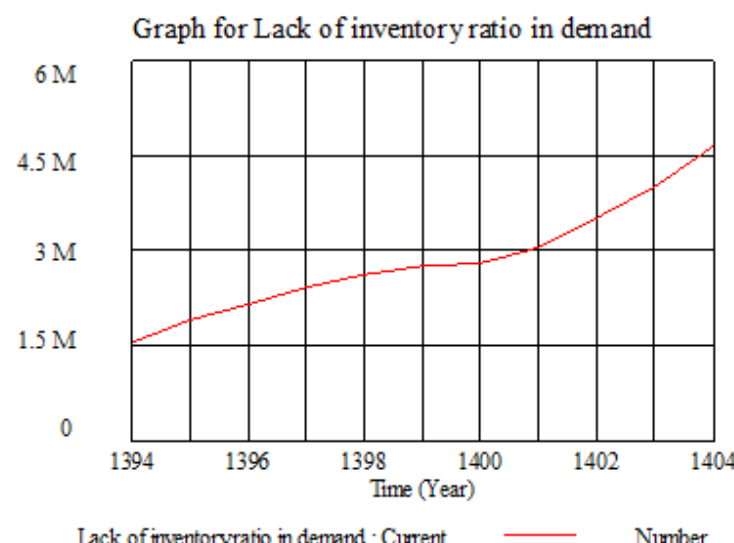

Lack of inventoryratio in demand: Current

Number

Figure 6. The result of simulation for variables of import and lack of stock to demand

According to the results of simulation, aims, mission, and perspective of Automotive Industry in Iran were suggested in four-aspect strategies according to Table 1.

Table 1

Suggested Strategies to Improve Supply Chain Performance of Automobile

\begin{tabular}{|c|c|c|}
\hline Suggested Strategy & Code & Aspect \\
\hline $\begin{array}{l}\text { Investment in Attracting Modern Technologies and Creating Competitive Advantage through Innovation in } \\
\text { the Product }\end{array}$ & F1 & \multirow[t]{3}{*}{$\begin{array}{l}\text { Automakers } \\
\text { (Production) }\end{array}$} \\
\hline Adding Value Added Due to the Creativity in Production & F2 & \\
\hline Developing International Cooperation to Increase Productive Capacity & F3 & \\
\hline Developing Systems of Providers’ Performance Evaluation & $\mathrm{C} 1$ & \multirow{3}{*}{$\begin{array}{l}\text { Provider (Part } \\
\text { Manufacturers) }\end{array}$} \\
\hline Developing Export Markets of Auto Parts and Equipment & $\mathrm{C} 2$ & \\
\hline Mutual Investment with Foreign Part and Set Manufacturers Owning Valid Brand & C3 & \\
\hline Gradual Decrease of Import Tariff based on Automotive Industry & I1 & \multirow[t]{3}{*}{ Government } \\
\hline Facilitating Needed Infrastructures and Legal Export Foundation & I2 & \\
\hline Modernizing Transportation & I3 & \\
\hline Improving Voice of Customer through Developing Distribution Network and Decreasing the Delivery Time & L1 & \multirow{3}{*}{$\begin{array}{l}\text { Automakers } \\
\text { (Distribution, } \\
\text { Sale, After-Sales } \\
\text { Services, etc.) }\end{array}$} \\
\hline Attempting to Develop Export Markets of Automobile & L2 & \\
\hline Developing After-Sales Services to Increase Customer’s Satisfaction & L3 & \\
\hline
\end{tabular}

In the sixth step (selecting the optimum strategy using game theory), suggested strategies in Table 1 and all different mixed strategies of different aspects according to Table 2 are simulated. Based on the results of simulation, the value of utility (0 to 5), comparing with the perspective, and using experts' opinions, these strategies are devoted for each aspect (player). Then, the utility value of double, triple, and quadruple coalitions for each mixed strategy is calculated as the example:

$$
\text { UF,C(F1,C1,I2,L2) = UF(F1,C1,I2,L2) + UC(F1,C1,I2,L2) }
$$

Table 2 clearly indicates the structure of mixed strategies of different aspects in cooperative game with three strategies for each aspect. 
Table 2

The Structure of Mixed Strategies of Different Aspects in Cooperative Game with Three Strategies for each Aspect

\begin{tabular}{|c|c|c|c|c|c|c|c|c|c|c|}
\hline \multicolumn{11}{|c|}{$\begin{array}{c}\text { Game structure cooperation in the supply chain } \\
\text { Automakers aspect (production) }\end{array}$} \\
\hline & & $\mathrm{I}$ & & & II & & & III & & \\
\hline \multirow{18}{*}{$\begin{array}{l}\text { Automake } \\
\text { rs aspect } \\
\text { (distributi } \\
\text { on, sale, } \\
\text { etc) }\end{array}$} & \multirow{6}{*}{ I } & $\begin{array}{l}\text { Governm } \\
\text { ent I }\end{array}$ & $\begin{array}{l}\text { Governm } \\
\text { ent I }\end{array}$ & $\begin{array}{l}\text { Governm } \\
\text { ent I }\end{array}$ & $\begin{array}{l}\text { Governm } \\
\text { ent I }\end{array}$ & $\begin{array}{l}\text { Governm } \\
\text { ent I }\end{array}$ & $\begin{array}{l}\text { Governm } \\
\text { ent I }\end{array}$ & $\begin{array}{l}\text { Governm } \\
\text { ent I }\end{array}$ & $\begin{array}{l}\text { Governm } \\
\text { ent I }\end{array}$ & $\begin{array}{l}\text { Governm } \\
\text { ent I }\end{array}$ \\
\hline & & Supplier I & $\begin{array}{l}\text { Supplier } \\
\text { II }\end{array}$ & $\begin{array}{l}\text { Supplier } \\
\text { III }\end{array}$ & Supplier I & $\begin{array}{l}\text { Supplier } \\
\text { II }\end{array}$ & $\begin{array}{l}\text { Supplier } \\
\text { III }\end{array}$ & Supplier I & $\begin{array}{l}\text { Supplier } \\
\text { II }\end{array}$ & $\begin{array}{l}\text { Supplier } \\
\text { III }\end{array}$ \\
\hline & & $\begin{array}{l}\text { Governm } \\
\text { ent II }\end{array}$ & $\begin{array}{l}\text { Governm } \\
\text { ent II }\end{array}$ & $\begin{array}{l}\text { Governm } \\
\text { ent II }\end{array}$ & $\begin{array}{l}\text { Governm } \\
\text { ent II }\end{array}$ & $\begin{array}{l}\text { Governm } \\
\text { ent II }\end{array}$ & $\begin{array}{l}\text { Governm } \\
\text { ent II }\end{array}$ & $\begin{array}{l}\text { Governm } \\
\text { ent II }\end{array}$ & $\begin{array}{l}\text { Governm } \\
\text { ent II }\end{array}$ & $\begin{array}{l}\text { Governm } \\
\text { ent II }\end{array}$ \\
\hline & & Supplier I & $\begin{array}{l}\text { Supplier } \\
\text { II }\end{array}$ & $\begin{array}{l}\text { Supplier } \\
\text { III }\end{array}$ & Supplier I & $\begin{array}{l}\text { Supplier } \\
\text { II }\end{array}$ & $\begin{array}{l}\text { Supplier } \\
\text { III }\end{array}$ & Supplier I & $\begin{array}{l}\text { Supplier } \\
\text { II }\end{array}$ & $\begin{array}{l}\text { Supplier } \\
\text { III }\end{array}$ \\
\hline & & $\begin{array}{l}\text { Governm } \\
\text { ent III }\end{array}$ & $\begin{array}{l}\text { Governm } \\
\text { ent III }\end{array}$ & $\begin{array}{l}\text { Governm } \\
\text { ent III }\end{array}$ & $\begin{array}{l}\text { Governm } \\
\text { ent III }\end{array}$ & $\begin{array}{l}\text { Governm } \\
\text { ent III }\end{array}$ & $\begin{array}{l}\text { Governm } \\
\text { ent III }\end{array}$ & $\begin{array}{l}\text { Governm } \\
\text { ent III }\end{array}$ & $\begin{array}{l}\text { Governm } \\
\text { ent III }\end{array}$ & $\begin{array}{l}\text { Governm } \\
\text { ent III }\end{array}$ \\
\hline & & Supplier I & $\begin{array}{l}\text { Supplier } \\
\text { II }\end{array}$ & $\begin{array}{l}\text { Supplier } \\
\text { III }\end{array}$ & Supplier I & $\begin{array}{l}\text { Supplier } \\
\text { II }\end{array}$ & $\begin{array}{l}\text { Supplier } \\
\text { III }\end{array}$ & Supplier I & $\begin{array}{l}\text { Supplier } \\
\text { II }\end{array}$ & $\begin{array}{l}\text { Supplier } \\
\text { III }\end{array}$ \\
\hline & \multirow{6}{*}{ II } & $\begin{array}{l}\text { Governm } \\
\text { ent I }\end{array}$ & $\begin{array}{l}\text { Governm } \\
\text { ent I }\end{array}$ & $\begin{array}{l}\text { Governm } \\
\text { ent I }\end{array}$ & $\begin{array}{l}\text { Governm } \\
\text { ent I }\end{array}$ & $\begin{array}{l}\text { Governm } \\
\text { ent I }\end{array}$ & $\begin{array}{l}\text { Governm } \\
\text { ent I }\end{array}$ & $\begin{array}{l}\text { Governm } \\
\text { ent I }\end{array}$ & $\begin{array}{l}\text { Governm } \\
\text { ent I }\end{array}$ & $\begin{array}{l}\text { Governm } \\
\text { ent I }\end{array}$ \\
\hline & & Supplier I & $\begin{array}{l}\text { Supplier } \\
\text { II }\end{array}$ & $\begin{array}{l}\text { Supplier } \\
\text { III }\end{array}$ & Supplier I & $\begin{array}{l}\text { Supplier } \\
\text { II }\end{array}$ & $\begin{array}{l}\text { Supplier } \\
\text { III }\end{array}$ & Supplier I & $\begin{array}{l}\text { Supplier } \\
\text { II }\end{array}$ & $\begin{array}{l}\text { Supplier } \\
\text { III }\end{array}$ \\
\hline & & $\begin{array}{l}\text { Governm } \\
\text { ent II }\end{array}$ & $\begin{array}{l}\text { Governm } \\
\text { ent II }\end{array}$ & $\begin{array}{l}\text { Governm } \\
\text { ent II }\end{array}$ & $\begin{array}{l}\text { Governm } \\
\text { ent II }\end{array}$ & $\begin{array}{l}\text { Governm } \\
\text { ent II }\end{array}$ & $\begin{array}{l}\text { Governm } \\
\text { ent II }\end{array}$ & $\begin{array}{l}\text { Governm } \\
\text { ent II }\end{array}$ & $\begin{array}{l}\text { Governm } \\
\text { ent II }\end{array}$ & $\begin{array}{l}\text { Governm } \\
\text { ent II }\end{array}$ \\
\hline & & Supplier I & $\begin{array}{l}\text { Supplier } \\
\text { II }\end{array}$ & $\begin{array}{l}\text { Supplier } \\
\text { III }\end{array}$ & Supplier I & $\begin{array}{l}\text { Supplier } \\
\text { II }\end{array}$ & $\begin{array}{l}\text { Supplier } \\
\text { III }\end{array}$ & Supplier I & $\begin{array}{l}\text { Supplier } \\
\text { II }\end{array}$ & $\begin{array}{l}\text { Supplier } \\
\text { III }\end{array}$ \\
\hline & & $\begin{array}{l}\text { Governm } \\
\text { ent III }\end{array}$ & $\begin{array}{l}\text { Governm } \\
\text { ent III }\end{array}$ & $\begin{array}{l}\text { Governm } \\
\text { ent III }\end{array}$ & $\begin{array}{l}\text { Governm } \\
\text { ent III }\end{array}$ & $\begin{array}{l}\text { Governm } \\
\text { ent III }\end{array}$ & $\begin{array}{l}\text { Governm } \\
\text { ent III }\end{array}$ & $\begin{array}{l}\text { Governm } \\
\text { ent III }\end{array}$ & $\begin{array}{l}\text { Governm } \\
\text { ent III }\end{array}$ & $\begin{array}{l}\text { Governm } \\
\text { ent III }\end{array}$ \\
\hline & & Supplier I & $\begin{array}{l}\text { Supplier } \\
\text { II }\end{array}$ & $\begin{array}{l}\text { Supplier } \\
\text { III }\end{array}$ & Supplier I & $\begin{array}{l}\text { Supplier } \\
\text { II }\end{array}$ & $\begin{array}{l}\text { Supplier } \\
\text { III }\end{array}$ & Supplier I & $\begin{array}{l}\text { Supplier } \\
\text { II }\end{array}$ & $\begin{array}{l}\text { Supplier } \\
\text { III }\end{array}$ \\
\hline & \multirow{6}{*}{$\begin{array}{l}\text { II } \\
\text { I }\end{array}$} & $\begin{array}{l}\text { Governm } \\
\text { ent I }\end{array}$ & $\begin{array}{l}\text { Governm } \\
\text { ent I }\end{array}$ & $\begin{array}{l}\text { Governm } \\
\text { ent I }\end{array}$ & $\begin{array}{l}\text { Governm } \\
\text { ent I }\end{array}$ & $\begin{array}{l}\text { Governm } \\
\text { ent I }\end{array}$ & $\begin{array}{l}\text { Governm } \\
\text { ent I }\end{array}$ & $\begin{array}{l}\text { Governm } \\
\text { ent I }\end{array}$ & $\begin{array}{l}\text { Governm } \\
\text { ent I }\end{array}$ & $\begin{array}{l}\text { Governm } \\
\text { ent I }\end{array}$ \\
\hline & & Supplier I & $\begin{array}{l}\text { Supplier } \\
\text { II }\end{array}$ & $\begin{array}{l}\text { Supplier } \\
\text { III }\end{array}$ & Supplier I & $\begin{array}{l}\text { Supplier } \\
\text { II }\end{array}$ & $\begin{array}{l}\text { Supplier } \\
\text { III }\end{array}$ & Supplier I & $\begin{array}{l}\text { Supplier } \\
\text { II }\end{array}$ & $\begin{array}{l}\text { Supplier } \\
\text { III }\end{array}$ \\
\hline & & $\begin{array}{l}\text { Governm } \\
\text { ent II }\end{array}$ & $\begin{array}{l}\text { Governm } \\
\text { ent II }\end{array}$ & $\begin{array}{l}\text { Governm } \\
\text { ent II }\end{array}$ & $\begin{array}{l}\text { Governm } \\
\text { ent II }\end{array}$ & $\begin{array}{l}\text { Governm } \\
\text { ent II }\end{array}$ & $\begin{array}{l}\text { Governm } \\
\text { ent II }\end{array}$ & $\begin{array}{l}\text { Governm } \\
\text { ent II }\end{array}$ & $\begin{array}{l}\text { Governm } \\
\text { ent II }\end{array}$ & $\begin{array}{l}\text { Governm } \\
\text { ent II }\end{array}$ \\
\hline & & Supplier I & $\begin{array}{l}\text { Supplier } \\
\text { II }\end{array}$ & $\begin{array}{l}\text { Supplier } \\
\text { III }\end{array}$ & Supplier I & $\begin{array}{l}\text { Supplier } \\
\text { II }\end{array}$ & $\begin{array}{l}\text { Supplier } \\
\text { III }\end{array}$ & Supplier I & $\begin{array}{l}\text { Supplier } \\
\text { II }\end{array}$ & $\begin{array}{l}\text { Supplier } \\
\text { III }\end{array}$ \\
\hline & & $\begin{array}{l}\text { Governm } \\
\text { ent III }\end{array}$ & $\begin{array}{l}\text { Governm } \\
\text { ent III }\end{array}$ & $\begin{array}{l}\text { Governm } \\
\text { ent III }\end{array}$ & $\begin{array}{l}\text { Governm } \\
\text { ent III }\end{array}$ & $\begin{array}{l}\text { Governm } \\
\text { ent III }\end{array}$ & $\begin{array}{l}\text { Governm } \\
\text { ent III }\end{array}$ & $\begin{array}{l}\text { Governm } \\
\text { ent III }\end{array}$ & $\begin{array}{l}\text { Governm } \\
\text { ent III }\end{array}$ & $\begin{array}{l}\text { Governm } \\
\text { ent III }\end{array}$ \\
\hline & & Supplier I & $\begin{array}{l}\text { Supplier } \\
\text { II }\end{array}$ & $\begin{array}{l}\text { Supplier } \\
\text { III }\end{array}$ & Supplier I & $\begin{array}{l}\text { Supplier } \\
\text { II }\end{array}$ & $\begin{array}{l}\text { Supplier } \\
\text { III }\end{array}$ & Supplier I & $\begin{array}{l}\text { Supplier } \\
\text { II }\end{array}$ & $\begin{array}{l}\text { Supplier } \\
\text { III }\end{array}$ \\
\hline
\end{tabular}

Table 3 indicates the normal form of utility for one of the possible triple coalitions.

Table 3

Normal form of Utility for Coalition $(F, I, L)$

\begin{tabular}{|c|c|c|c|c|c|}
\hline & & $\mathrm{C}_{\mathrm{i}}$ & 1 & 2 & 3 \\
\hline$F_{i}$ & $\mathrm{I}_{\mathrm{i}}$ & $\mathrm{L}_{\mathrm{i}}$ & & & \\
\hline 1 & 1 & 1 & 8 & 6 & 6 \\
\hline 1 & 1 & 2 & 10 & 7 & 7 \\
\hline 1 & 1 & 3 & 7 & 8 & 9 \\
\hline 1 & 2 & 1 & 5 & 9 & 9 \\
\hline 1 & 2 & 2 & 6 & 3 & 7 \\
\hline 1 & 2 & 3 & 1 & 4 & 13 \\
\hline 1 & 3 & 1 & 6 & 9 & 6 \\
\hline 1 & 3 & 2 & 7 & 8 & 9 \\
\hline 1 & 3 & 3 & 5 & 6 & 6 \\
\hline 2 & 1 & 1 & 4 & 9 & 10 \\
\hline 2 & 1 & 2 & 7 & 10 & 6 \\
\hline 2 & 1 & 3 & 9 & 6 & 7 \\
\hline 2 & 2 & 1 & 9 & 2 & 9 \\
\hline
\end{tabular}




\begin{tabular}{llllll}
2 & 2 & 2 & 7 & 12 & 7 \\
2 & 2 & 3 & 8 & 6 & 14 \\
2 & 3 & 1 & 2 & 6 & 11 \\
2 & 3 & 2 & 10 & 10 & 4 \\
2 & 3 & 3 & 8 & 11 & 6 \\
3 & 1 & 1 & 11 & 9 & 9 \\
3 & 1 & 2 & 8 & 8 & 10 \\
3 & 1 & 3 & 5 & 6 & 10 \\
3 & 2 & 1 & 9 & 9 & 8 \\
3 & 2 & 2 & 12 & 8 & 2 \\
3 & 2 & 3 & 6 & 11 & 10 \\
3 & 3 & 1 & 13 & 6 & 12 \\
3 & 3 & 2 & 9 & 10 & 8 \\
3 & 3 & 3 & 11 & 13 & 5 \\
\hline
\end{tabular}

The value of function $\mathrm{V}(\mathrm{C})$ from one coalition to a normal form (two-dimensional) has the characteristics of a saddle point. Max-min in the row and min-max in the column in a saddle point are consistent with one another, since coalition joiners in the row try to maximize their utility and non-coalition joiners in the column try to minimize the most loss. Although noncoalition joiners may always have positive earnings, fewer earnings for coalition-joiners may increase their earnings. If $C_{i j}$ indicates the coalition utility of row $\mathrm{i}$ and column $\mathrm{j}$ in the coalition matrix (coalition c), so that row i shows a combination of coalition strategies and column j shows a combination of non-coalition strategies; V(C) will be calculated by solving the linear planning (3):

(3)

$$
\begin{gathered}
V(C)=\operatorname{Max}: Z \\
S T: \\
Z \leq \sum_{i} P_{i} * C_{i j} \rightarrow \forall j \\
P_{i} \geq 0 \\
Z: \text { free }
\end{gathered}
$$

Pi determines the probability of selection for the coalition joiners (from the mixed strategies in row i). To calculate the function of characteristics for different coalitions of different suggested aspects, the linear planning (3) is written according to its coalition matrix and the value of $\mathrm{V}(\mathrm{C})$ for each coalition is calculated by solving the model through Lingo 11 Software. Table 4 shows the function of characteristics of coalition.

Table 4

The Function of Characteristics of Coalition

\begin{tabular}{ll|ll}
\hline & V & & V \\
\hline V (F) & 1.25 & V (C, L) & 5.51 \\
V (C) & 1.81 & V (C, I) & 5.5 \\
V (I) & 1 & V (F, C, I) & 10.86 \\
V (L) & 0.9 & V (F, C, L) & 11.18 \\
V (F, C) & 5.31 & V (F, I, L) & 9.62 \\
V (F, I) & 5.57 & V (C, I, L) & 12 \\
V (F, L) & 5.4 & V (F, C, I, L) & 19 \\
V (I, L) & 5.25 & & \\
\hline
\end{tabular}


Shapley value of each player in equation (2-2) for each player (aspect) is calculated through Table 5.

Table 4

Shapley Value of Payers (Aspect)

\begin{tabular}{ll} 
& Shapley Value \\
\hline F & 3.78 \\
C & 5.37 \\
I & 2.58 \\
L & 4.63 \\
\hline
\end{tabular}

According to the calculated Shapley value for players, $C>L>I>F$ shows the order of their power and sensitivity in the coalition; thus, it plays a leading role in selecting the mixed strategy for implementing the provider aspect. Based on this selection, auto making aspect (distribution and sale), government aspect, and automaker aspect (production) respectively select the strategy for receiving the best earnings.

\section{Discussion and Conclusion}

The result of selecting the best strategy indicates that the first and effective aspect in automotive industry to gain the perspective is the provider aspect (related to the part manufacturer). The first strategy in this regard is to develop the evaluation systems of providers' performance. Due to the Automotive Industry in Iran and the rapid growth of this industry as well as domestic competitors and the probability of foreign competitors, the performance of makers must be compared with competitive indices and their weaknesses must be identified and revealed. Therefore, the necessity of evaluating and selecting the makers in order to promote their performance has been increased. After this evaluation, making decision about conditions of purchase, paying supportive facilities, and solutions on guiding the makers are of great importance. Automotive Industry in Iran paid great attention to this evaluation. Therefore, the evaluation systems of providers' performance must be developed in this industry.

Other important strategy is to develop the export markets of auto parts. Since in recent years the abilities to design and make auto parts in the country have improved, exporting auto parts can be the first step to enter the export markets. Therefore, due to the importance of nonoil exports in the country's five-year plan, formulating a long-term strategy of export for the Automotive Industry especially for auto parts seems necessary.

Other important strategy in this aspect is to develop foreign investment and create mutual brand of auto parts. At present, most activities of foreign investors in Automotive Industry in Iran are devoted to designing, making, and producing mechanical and electronic parts. However, the Automotive Industry always attempts to attract foreign investment to develop its infrastructure and automakers try to invite foreign automakers to develop the Automotive Industry. Automakers believe that the supports of law for foreign investment in the country especially financial support and the growing demand of Iran's markets can change Iran into the center of producing high-quality automobiles in the Middles East. 
Iran has made some attempts to develop the Automotive Industry, however, its speed was so slow. Reviewing the policies of countries compared with Iran on the Automotive Industry can help to understand the reasons of growth in this industry in Iran.

The results of this research indicated that one of the most important strategies to improve the Automotive Industry in Iran is to increase the engineering knowledge and the ability to develop the product simultaneous with the automotive industry in the world and sell the products in foreign markets.

\section{References}

Afonso, H., \& Rosario Cabrita, M. (2015). Developing a lean supply chain performance framework in a SME: A perspective based on the balanced scorecard. Procedia Engineering, 131, 270-279.

Azar, A., Moghabel-Baarz, A., \& Anvari Rostami, A. (2011). Designing an agile supply chain: Interpretative-Structural Modeling (ISM) approach. Management Research in Iran, 14(4), 1-25.

Chang, W., \& Ellinger, A. E. (2014). Evaluating supply chain risk mitigation strategy. In L. Robinson (Ed.), Marketing dynamism and sustainability: Things change, things stay the same (pp. 594-595). New York City: Springer International Publishing.

Chopra, S., \& Meindl, P. (2007). Supply chain management: Strategy, planning, and operation. New Jersey: Perason Prentice Hall.

Jalali Naini, S., Aliahmadi, A., \& Jafari Eskandari, M. (2011). Designing a mixed performance measurement system for environmental supply chain management using evolutionary game theory and balanced scorecard: A case study of an auto industry supply chain. Resources, Conservation, and Recycling, 55(6), 593-603.

Leng, M., \& Parlar, M. (2005). Game theoretic applications in supply chain management: A review. INFOR: Information Systems and Operational Research, 43(3), 187-220.

Norang, A., \& Mehryar Irdimousa, H. (2012). Developing the evaluation model of the performance of supply chain management using balanced scorecard. Noor Magazines, 34, 48-61.

Rezaee Ghahraman, M., Aghaseyyed Hosseini, S., \& Ahmadian, A. (2012). Twelve steps in formulating and implementing balanced scorecard and determining performance indices. Tehran, Iran: Yazda Publications.

Saad, S., Mohamed Udin, Z. M., \& Hasnan, N. (2014). Dynamic supply chain capabilities: A case study in oil and gas industry. International Journal of Supply Chain Management, 3(2), 70-76.

Stadtler, H., \& Kilger, C. (2004). Supply chain management and advanced planning (R. Zanjirani Farahani \& N. Asgari, Trans.). Tehran, Iran: Termeh.

Sushil, S. K. (2014). System dynamics (E. Teymouri \& A. Nourali \& N. Valizadeh, Trans.). Tehran, Iran: Iran University of Science \& Technology.

Tatikonda, L. U., \& Tatikonda, R. J. (1998). We need dynamic performance measures. Management Accounting, 80(3), 4953.

Tian, Y., Govindan, K., \& Zhu, Q. (2014). A system dynamics model based on evolutionary game theory for green supply chain management diffusion among Chinese manufacturers. Journal of Cleaner Production, 80, 96-105. 